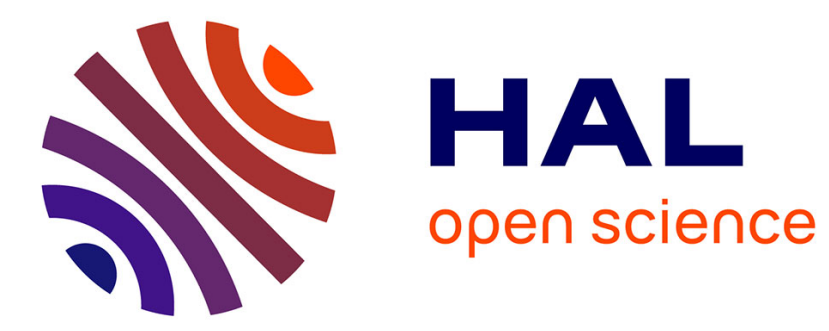

\title{
Participation and Political Competition in Committee Report Allocation
}

\author{
Pierre Hausemer
}

\section{To cite this version:}

Pierre Hausemer. Participation and Political Competition in Committee Report Allocation. European Union Politics, 2006, 7 (4), pp.505-530. 10.1177/1465116506069441 . hal-00571735

\section{HAL Id: hal-00571735 \\ https://hal.science/hal-00571735}

Submitted on 1 Mar 2011

HAL is a multi-disciplinary open access archive for the deposit and dissemination of scientific research documents, whether they are published or not. The documents may come from teaching and research institutions in France or abroad, or from public or private research centers.
L'archive ouverte pluridisciplinaire HAL, est destinée au dépôt et à la diffusion de documents scientifiques de niveau recherche, publiés ou non, émanant des établissements d'enseignement et de recherche français ou étrangers, des laboratoires publics ou privés. 


\section{EUP}

European Union Politics

DOI: $10.1177 / 1465116506069441$

Volume 7 (4): 505-530

Copyright(C) 2006

SAGE Publications

London, Thousand Oaks CA,

New Delhi

\section{KEY WORDS}

- European Parliament

- legislative behaviour

- party competition

- report allocation

- representation

\section{Participation and Political} Competition in Committee Report Allocation

\author{
Under What Conditions Do MEPs \\ Represent Their Constituents?
}

\author{
Pierre Hausemer \\ London School of Economics, UK
}

\section{ABSTRACT}

The paper models the consequences of committee report allocation for political representation in the European Parliament (EP). The range of legislators involved in each policy area affects the values, interests and constituencies that the Parliament represents. Thus, representation is defined as an MEP's participation in salient policy areas. The allocation of salient reports follows inter- and intra-party group dynamics. First, party groups compete for salient reports in a context of open voting rules in committee and plenum. Second, group coordinators distribute these reports among their MEPs in an attempt to maximize the cohesion of the group. The model is tested on data from the fifth European Parliament (1999-2002). The results confirm the impact of selective participation on political representation. The EP has evolved into a 'normal' Parliament featuring coalitions and competition along a left-right cleavage across party groups and a hierarchical allocation of legislative spoils within parties. 


\section{Introduction}

Over the past 20 years, the European Parliament (EP) has assumed increasing power within the European Union's political system. This was accompanied by growing interest in the 'democratic credentials' of the European Union (EU) and its Parliament. Research on political representation in the EU, however, has either taken a macro-level approach (for a discussion of this literature see, e.g., Follesdal and Hix, 2005) or focused on the role of European elections in selecting appropriate representatives (e.g. Van der Eijk and Franklin, 1996; Norris and Franklin, 1997; Schmitt and Thomassen, 1999).

Yet the solution to the so-called democratic deficit does not lie solely in the institutional set-up of the European Union or the social make-up of its Parliament. Rather, it is the legislative participation of individual MEPs that determines whose opinions are represented. As Hall (1996) points out in his seminal study on participation in the US Congress, purposive legislators engage in different legislative activities and policy areas depending on the structure of opportunities and constraints that they face. Similarly to Congress, such 'selective participation' has wide-ranging consequences for political representation in the European Parliament. The range of members involved in legislative business, be it in committees or in the plenum, determines the values, interests and constituencies that the Parliament represents. Consistent representational bias could undermine the legitimacy of a fledgling supranational parliamentary system.

Nevertheless, little is known about the legislative participation of individual MEPs outside roll-call voting sessions. This paper contributes to filling this gap by developing and testing a model of political representation in the allocation of committee reports in the European Parliament. Which MEPs obtain the most salient committee reports? And what are the consequences for constituency representation? The paper conceives reports as legislative tools used by individual legislators to represent the preferences of their national parties. The study contributes to the existing research programmes on political representation, report allocation and the internal organization of the European Parliament.

I first introduce a conception of political representation based on the legislative participation of individual MEPs. I then discuss existing studies of report allocation in the European Parliament and outline the contribution of this paper to the research programme. My theoretical model explains the consequences of selective participation in committee reports for political representation and derives a set of hypotheses to be tested in the next section. I conclude with a summary of the results and an indication of possible areas for future research. 


\section{Political representation and representational focus in the EP}

Most students of the European Parliament have analysed 'indirect representation', or what Pitkin (1967) calls descriptive or formalistic notions of representation. Indirect representation occurs when voters select like-minded representatives to implement policies that are in their interest (Wlezien, 2004). Research on indirect representation asks how and to what extent the range of political opinions within the public is translated into parliamentary seats. In the European Parliament, this literature has focused on either European elections (Reif and Schmitt, 1980; Bowler and Farrell, 1993; Van der Eijk and Franklin, 1996; Carrubba, 2001), or representative role perceptions (Thomassen and Schmitt, 1997; Katz, 1997, 1999; Marsh and Wessels, 1997; Schmitt and Thomassen, 1999, 2000; Wessels, 1999), or the social characteristics of representatives (Norris and Franklin, 1997). Most of this research has concluded that representation in the EP works only moderately well at best: the electoral connection is weaker than in domestic parliamentary systems, MEPs have different preferences on specific policy issues than their constituents, and the EP as a whole is socially quite unrepresentative.

In contrast, 'direct' or - in Pitkin's (1967) words - 'substantive' representation refers to policy responsiveness in the legislative behaviour of sitting politicians (Wlezien, 2004). This research programme investigates to what extent the political preferences of European citizens are reflected in the legislative behaviour of their representatives and in the policy outcomes they produce. As Moravcsik and Sangiovanni (2002) point out, we can determine EU responsiveness to underlying national moods by measuring the impact of constituency preferences on policy and regulatory outcomes at the European level. Most of this literature has focused on normative questions and the institutional setup of the EU (Scharpf, 1999; Majone, 2000; Moravcsik, 2002; Crombez, 2003; Follesdal and Hix, 2005).

This paper adds an empirical dimension to the research programme on 'direct representation' in the EP. In line with Wlezien's (2004) definition, policy responsiveness is a function of the legislative behaviour of individual MEPs. Representation occurs when MEPs engage in policy areas that are important to their constituents and thus follows what others have called a 'competence logic' (Schmitt and Thomassen, 2000). The more competently legislators address policy issues that are salient to those they represent, the better their representational performance. Conversely, the more energy representatives expend on policy areas that are not of interest to constituents, the lower their representational performance. Thus, 'selective participation' in a small number of legislative activities and policy areas has direct implications for political representation (Hall, 1996). 
Such a behavioural conception of political representation does not, however, answer the question of the appropriate representational focus. Table 1 shows the results of a survey in which MEPs were asked who they think they should represent. It becomes immediately clear that national party voters and the constituency or country, respectively, are at the centre of most MEPs' representational roles. More than $70 \%$ of MEPs see their role primarily as representing the people in their country, followed closely by $67 \%$ who are very concerned about representing their national party voters. The narrowest (special groups) and the widest (all Europeans) representational foci are far less popular, with $21 \%$ and $41 \%$ respectively.

Thus, territorial (country) and ideological (party) cleavages define the representational roles of MEPs. However, a plethora of recent empirical research has confirmed that ideological politics has gradually come to dominate legislative decision-making in the European Parliament. In an indepth study of MEPs' roll-call voting records over the full five terms of the European Parliament, Hix et al. (forthcoming, 2004), for instance, find that the

Table 1 Representational foci of MEPs (\%)

\begin{tabular}{llllll}
\hline & $\begin{array}{l}\text { All people } \\
\text { in Europe }\end{array}$ & $\begin{array}{l}\text { All people } \\
\text { in country }\end{array}$ & Constituency & $\begin{array}{l}\text { Party } \\
\text { voters }\end{array}$ & $\begin{array}{l}\text { Special } \\
\text { groups }\end{array}$ \\
\hline Austria & 30 & 70 & 60 & 80 & 50 \\
Belgium & 39 & 44 & 72 & 67 & 11 \\
Denmark & 25 & 63 & 13 & 75 & - \\
Finland & 18 & 91 & 73 & 73 & 9 \\
France & 44 & 56 & 31 & 61 & 14 \\
Germany & 63 & 57 & 59 & 50 & 17 \\
Greece & 73 & 91 & 55 & 64 & 27 \\
Ireland & 44 & 89 & 89 & 89 & 33 \\
Italy & 65 & 74 & 41 & 50 & 20 \\
Luxembourg & - & 75 & 75 & 75 & 25 \\
Netherlands & 48 & 76 & 5 & 86 & 14 \\
Portugal & 31 & 81 & 56 & 38 & 19 \\
Spain & 42 & 67 & 69 & 78 & 28 \\
Sweden & 21 & 64 & 57 & 71 & 14 \\
UK & 29 & 54 & 79 & 50 & 14 \\
EU-15 & 40.86 & 70.13 & 55.6 & 67.13 & 21.07 \\
\hline
\end{tabular}

Source: Adapted from Wessels (1999).

Notes: Figures are percentages of representatives who indicated that the respective focus is of great importance to them (values 6 and 7 on a 7-point scale, where 1 indicates little importance and 7 great importance). Note that in the 1999 European elections most countries had only one electoral district, with the exception of the UK (12) and Belgium (3). 
legislative behaviour of MEPs is more closely aligned with their national party than with their European party group or their territorial constituency. Similarly, Jun (2003) notes that national parties are crucial in determining MEP behaviour in budgetary discharge votes. Høyland (2005) also finds systematic differences in the voting behaviour of MEPs along ideological lines. Finally, Whitaker $(2001,2005)$ concludes that national parties have increased their power over policy outcomes at the European level by assuming greater control over committee assignments and the direction of committee business as the powers of the EP increased. In line with these findings, the discussion in this paper focuses on national party voters as an MEP's primary constituency.

Of course, incentives to represent the party constituency vary across national political systems. Hix (2004) as well as Farrell and Scully (2002) show that the domestic political systems in which MEPs compete for votes differ dramatically. In some member states, electoral districts are small, candidate selection is highly centralized and ballots for European elections are closed, which attributes substantial selection powers to the party leadership (Hix, 2004). MEPs from these countries are likely to be particularly concerned with representing the preferences of their national parties. As Kreppel (2002) notes, party influence over electoral lists may give rise to a true 'electoral connection' between MEPs and their national parties, if not their home electorate. In other member states, selection procedures are more decentralized, with open ballots and larger districts, which reduces candidate dependency on the party leadership (Hix, 2004). Any empirical assessment of political representation must therefore account for differences in electoral systems across member states.

This section has introduced a conception of 'direct' political representation based on the policy responsiveness of individual legislators. The remainder of this paper applies this conception of representation to committee reports in the European Parliament.

\section{Committee reports in the European Parliament}

Most scholars agree that the production of legislative reports is one of the most important elements of parliamentary committee work (Mamadouh and Raunio, 2001, 2003; Corbett et al., 2003; Kaeding, 2004, 2005). Indeed, the system of rapporteurships enables individual legislators to take responsibility for, and exert influence over, the policy position of the Parliament as a whole. As Benedetto (2005: 67) notes, the distribution of reports among MEPs 'allows us to conclude which parties and nationalities ... have an impact on the content of European legislation'. Thus, maybe more than in other legislative 
activities, 'selective participation' in committee reports considerably affects the range of political opinions that are represented in a particular policy area. This section describes the process of report allocation and discusses previous research on committee reports.

Topics for reports either are forwarded from the Council or the Commission under the different decision-making procedures or they arise at the initiative of an individual MEP. Despite the introduction of quotas on own-initiative reports in 1994, the workload of the Parliament has continued to increase in tandem with its policy influence (Corbett et al., 2003). As Table 2 illustrates, the number of reports has risen by $20 \%$ over the 10 -year period. One in five reports in the fifth Parliament fell under the co-decision procedure, where the European Parliament acts as a co-legislator with the Council of Ministers (Crombez, 1997; Tsebelis and Garrett, 2000). Most reports in the fifth Parliament were written in the Environment committee, followed by Justice and Home Affairs. In the previous legislature, Economics and Environment were vastly more prolific than other committees.

Each time a committee takes on a report, a rapporteur is nominated to draw up a draft text for approval by the committee. The bidding system within each committee favours a proportional allocation of reports among party groups according to the size of their delegation. At the same time, the system allows for a substantial amount of horse-trading among groups (Corbett et al., 2003). Group coordinators allocate the reports they have won to 'their' MEPs. Once nominated, rapporteurs are in charge of researching, writing and defending their text in committee and plenum, where it is voted upon by all members under the open rule. The open rule ensures that the report does not stray far from the median MEP in the legislature, regardless of the party affiliation or policy preferences of the rapporteur.

Several recent studies have analysed the factors that determine report allocation in the EP. Benedetto (2005) explains the distribution of reports among party groups and member states as part of an 'institutionalised consensus' within the EP. Mamadouh and Raunio (2001, 2003) and Kreppel (2002) single out national party delegations as 'key gatekeepers' within each party group. They find that intra-party group allocation is largely proportional to the size of national parties, whereas 'partisan interests drive the allocation process' across groups (Mamadouh and Raunio, 2001). In contrast, Høyland (2005) shows that governing and opposition parties have different strategies for spending their rights to co-decision reports. Governing parties aim to write as many reports as possible, whereas 'opposition parties choose their involvement more carefully'. Whitaker (2001) focuses on the role of group coordinators who bid on behalf of their groups and allocate reports to individual MEPs. As he points out, 'co-ordinators, at least subject to their 
Table 2 Number of reports by committee in the fourth and fifth parliaments

\begin{tabular}{|c|c|c|c|c|c|}
\hline \multicolumn{3}{|l|}{ 1994-1999 } & \multicolumn{3}{|l|}{ 1999-2004 } \\
\hline Committee & $A / l$ & $\begin{array}{l}\text { Co- } \\
\text { decision }\end{array}$ & Committee & $A / l$ & $\begin{array}{l}\text { Co- } \\
\text { decision }\end{array}$ \\
\hline Economics & 288 & 73 & Environment (ENVI) & 263 & 152 \\
\hline Environment & 207 & 86 & $\begin{array}{l}\text { Justice \& Home } \\
\text { Affairs (LIBE) }\end{array}$ & 254 & 19 \\
\hline Transport & 165 & 27 & $\begin{array}{l}\text { Legal Affairs \& } \\
\text { Internal Market (JURI) }\end{array}$ & 229 & 82 \\
\hline $\begin{array}{l}\text { External Economic } \\
\text { Relations }\end{array}$ & 129 & 1 & $\begin{array}{l}\text { Trade, Research \& } \\
\text { Energy (INDU) }\end{array}$ & 219 & 50 \\
\hline Foreign Affairs & 127 & 0 & $\begin{array}{l}\text { Economic and } \\
\text { Monetary Affairs } \\
\text { (ECON) }\end{array}$ & 190 & 35 \\
\hline Legal Affairs & 117 & 45 & $\begin{array}{l}\text { Budgetary Control } \\
\text { (CONT) }\end{array}$ & 176 & 3 \\
\hline Agriculture & 115 & 3 & $\begin{array}{l}\text { Foreign Affairs, } \\
\text { Democracy \& Human } \\
\text { Rights (AFET) }\end{array}$ & 153 & 2 \\
\hline Energy \& Research & 113 & 17 & $\begin{array}{l}\text { Agriculture \& Rural } \\
\text { Development (AGRI) }\end{array}$ & 147 & 15 \\
\hline Fisheries & 112 & 0 & $\begin{array}{l}\text { Regional Policy, } \\
\text { Transport \& Tourism } \\
\text { (RETT) }\end{array}$ & 147 & 78 \\
\hline Budgets & 104 & 2 & Budgets (BUDG) & 144 & 10 \\
\hline Employment & 99 & 12 & Fisheries (PESC) & 133 & 0 \\
\hline Civil Liberties & 97 & 4 & $\begin{array}{l}\text { Employment \& Social } \\
\text { Affairs (EMPL) }\end{array}$ & 109 & 30 \\
\hline Budgetary Control & 84 & 2 & $\begin{array}{l}\text { Development and } \\
\text { Cooperation (DEVE) }\end{array}$ & 73 & 18 \\
\hline Culture & 75 & 30 & $\begin{array}{l}\text { Constitutional Affairs } \\
\text { (AFCO) }\end{array}$ & 56 & 3 \\
\hline Development & 73 & 4 & $\begin{array}{l}\text { Culture, Youth, } \\
\text { Education, Media \& } \\
\text { Sport (CULT) }\end{array}$ & 51 & 25 \\
\hline Regional Policy & 70 & 2 & $\begin{array}{l}\text { Women's Rights \& } \\
\text { Equal Opps (FEMM) }\end{array}$ & 45 & 8 \\
\hline Rules of Procedure & 35 & 0 & Petitions (PETI) & 23 & 0 \\
\hline Women's Rights & 32 & 2 & & & \\
\hline Institutional Affairs & 24 & 0 & & & \\
\hline Petitions & 12 & 0 & & & \\
\hline TOTAL & 2078 & 310 & TOTAL & 2412 & 530 \\
\hline$\%$ Co-decision & 15 & & $\%$ Co-decision & 22 & \\
\hline
\end{tabular}

Sources: Corbett et al. (2003); http://www.europarl.eu.int.

Note: Committee abbreviations in brackets are used throughout the empirical analysis. 
personalities, have the potential to dominate committee activities and usurp the position of chair'.

From a slightly different angle, Kaeding's $(2004,2005)$ contributions focus on the level of individual MEPs. He shows that, in the Environment committee in the fourth Parliament, the group of rapporteurs did not mirror the composition of the legislature. Rather, rapporteurs tended to be (relatively pro-European) experts in the policy area that the report addresses. In a further analysis over several committees, Kaeding (2005) confirms that the 'world of committee reports' is characterized by disproportionality. Rapporteurs tend to be high demanders in the policy area that their report addresses. Whereas small member states focus on a restricted range of committees that are most important to them, larger member states are involved in all policy areas.

All of these studies have greatly enhanced our understanding of report allocation in the European Parliament. National parties and party group coordinators determine how reports are distributed along partisan lines. Policy expertise, attitudes towards European integration and the governing status of the national party affect an MEP's chances of obtaining a report. By accumulating policy expertise, building consensus among party groups and negotiating with the Council and the Commission, individual rapporteurs can acquire considerable leverage over policy outcomes at the European level (Mamadouh and Raunio, 2003).

Nevertheless, no study to date systematically investigates the consequences of report allocation for political representation in the European Parliament. As Benedetto (2005) recognizes, the selection of rapporteurs determines the range of political opinions that are represented in the policy positions of the European Parliament. Similarly, Mamadou and Raunio (2001) call for research on the effect of committee report allocation on EP legitimacy. The next section develops a theoretical model of political representation in committee reports and derives four hypotheses to be tested in subsequent sections.

\section{Representation and report allocation in the EP}

Like in national legislatures, representation in the European Parliament requires that party groups compete in elections and organize cohesively to implement their political platforms (Attinà, 1992; Andeweg, 1995; Van der Eijk and Franklin, 1996; Hix and Lord, 1997). In the inter-party mode, parties compete against one another for influence over policy, important offices within the legislature and/or the favours of the electorate. Within the party, hierarchy determines the interaction between rank-and-file members and the 
leadership (Weingast and Marshall, 1988; Müller, 2000; Boucek, 2002). This section uses the distinction between inter- and intra-party politics to develop a model of political representation in EP committee reports.

Most observers associate legislative politics primarily with the inter-party mode, where the governing coalition and the opposition confront one another, publicly debate policy issues and make decisions about a variety of policy alternatives. As long as a party (or a coalition of parties) holds a majority of votes in the legislature it determines the direction of policy and the allocation of parliamentary offices and other spoils. In the case of EP reports, this 'tyranny of the majority' is enforced under the open rule in the committee and in the plenum. The open rule in effect gives the majority coalition a veto over the contents of each report and forces minority MEPs to seek the support of (at least parts) of the majority in order to get their reports adopted. Thus, 'opposition' MEPs have little policy incentive to sign up for the most salient reports that are coveted by most party groups. In many cases, the prospect of defending the majority's report in the plenum and in conciliation is less appealing than trying to amend reports in committee or from the plenary backbenches. As a result, the distribution of salient reports mirrors coalition dynamics in the Parliament.

Scholars of coalition formation in the roll-call voting behaviour of MEPs have stressed different aspects of party group interaction. Some commentators emphasize the consensual nature of coalitions in the European assembly. High majority thresholds and an institutional structure that defines the Parliament in opposition to the Council of Ministers and the Commission undermine competition among party groups. According to these studies, the EP is dominated by 'grand coalitions' between the two main party groups, the European People's Party (EPP) and the Party of European Socialists (PES) (e.g. Bardi, 1994; Hix and Lord, 1997; Kreppel and Hix, 2003; Benedetto, 2005). Some more recent research on roll-call votes maintains that left-right policy preferences drive coalition formation. Most recently, Hix et al. (forthcoming) for instance find that the largest party group in the fifth Parliament, the conservative EPP, is more likely to coalesce with its closest partner along the left-right axis, the European Liberal Democrat and Reform group (ELDR), in order to form a winning majority than with the second-largest group (PES). Thus, if the distribution of salient reports mirrors coalition dynamics, MEPs from EPP and ELDR should write more salient reports than their peers from other party groups. Propped up by the double open rule in committee and plenum, EPP and ELDR legislators are able to represent their constituents in the policy areas that matter most to them. Extremist MEPs whose policy preferences are far from the median in the plenum, on the contrary, write reports only in the least salient policy areas. 
H1: MEPs whose party group forms part of the voting majority in the plenum (EPP and ELDR) write more salient reports than do MEPs from other party groups.

Inter-party competition is not the only dynamic at work in Western political systems. Parties are composed of individual members with their own policy preferences, constituencies and status within the party hierarchy. As Boucek (2002: 454) notes, 'parties are not unitary actors but collections of individuals ... with common but also divergent preferences and interests and with competing claims on party resources'. In these circumstances, the party group leadership must ensure the cohesion of the group by balancing the claims of party elites and rank-and-file without endangering the 'brand name' of the group (Boucek, 2002). ${ }^{1}$ In other words, cohesion is maintained, first, by distributing the group's resources so as to give all members a stake in its efficient operation and, second, by rewarding MEPs with policy preferences that are representative of the group.

First, parties ensure cohesion by influencing the behaviour of their members through the 'distribution of resources' (Weingast and Marshall, 1988: 159). As Hix (2002) points out, it is the larger national parties that essentially run the party groups. As a result, some MEPs from larger delegations take on less salient reports because their parties are involved in most committees, across a wide range of policy areas. By contrast, MEPs from smaller national parties have little power over the policy direction and the internal workings of their group. Instead, as Kaeding (2005) has shown at the level of the member states, they use their limited resources to focus on a small range of policy areas that are of particular salience to them. Rather than pushing MEPs from smaller national delegations into the least important policy areas, the party group leadership (i.e. the group coordinators) maintains cohesion by allowing these MEPs access to reports in the policy areas that are most salient to them.

H2: MEPs from smaller national parties write reports that are more salient to their parties than do MEPs from larger delegations.

Analogously, there is also a negative relation between committee rank and representation. Numerous interviews with practitioners have confirmed that committee chairmanships are among the most influential office positions in the EP (Whitaker, 2001, 2005). In return for such influence, it is part of the duty of committee chairs and other office holders to assume responsibility for reports that could not be allocated to other committee members (Corbett et al., 2003). On the other hand, like MEPs from small national parties, rankand-file committee members and substitutes focus on reports in the most salient policy areas. In order to maintain cohesion, higher-ranking committee 
officials and the group coordinators allow backbenchers to sign up for the most salient reports.

H3: Higher-ranking committee members (chairs and vice chairs) write reports that are less salient to their national parties than do rank-and-file members and substitutes.

Finally, the leadership ensures cohesion by rewarding loyal MEPs with policy preferences that are representative of the group as a whole. Even though legislators, on average, are likely to have more in common with their fellow party members than with the members of other parties (otherwise they would switch parties), this is not the case on all issues all the time. On any specific issue, individual members may disagree with and defect from the policy position of their party. By screening its members before allocating important legislative benefits, such as salient reports, the leadership can identify rebel backbenchers and reward representatives who toe (or at least are likely to toe) the party line. MEPs whose policy preferences are closest to the rest of their party group are most likely to be trusted with the most salient reports.

H4: Preference outliers write less salient reports than do MEPs whose policy preferences are close to the average of their party group.

This section has developed a theoretical model of political representation on European Parliament committee reports and derived four empirically testable hypotheses. The representational performance of individual legislators is determined jointly by the nature of political competition across party groups and by their internal organization. Legislative coalitions in the EP define the allocation of salient reports across groups. The leadership's concern with maintaining the cohesion of the group determines the distribution of salient reports within the party. The next section presents the data used to estimate the model.

\section{Data}

There are few theoretical indications that report allocation differs substantially between parliaments or over the course of a single legislature. As the party group leadership acquires better information about the policy preferences of its rank-and-file members, report allocation may increasingly reflect the expertise and background of individual MEPs. As a result, intra-party group politics may play a smaller role in the second half of each parliamentary term. Additionally, Høyland (2006) finds evidence for a government-opposition 
dynamic between Council and EP. National parties that are represented in the Council write more co-decision reports than do 'opposition' MEPs. However, as Høyland (2006) acknowledges, this effect is eclipsed by the importance of the party groups. PES representatives are 'more active than governing parties as co-decision rapporteurs'. Nevertheless, a larger data set over the full parliamentary term could help in evaluating the impact of information updates and national party competition on report allocation.

However, several exogenous factors, including committee reforms, midterm turnover and EU enlargement, could obfuscate the conclusions of a study over a longer period of time. First, the 1999 committee reform reduced the number of committees from 20 in the fourth Parliament to 17 in the fifth. This was raised back to 20 in 2004 when subcommittees were introduced to ease pressure on further enlargement of the committee system (McElroy, 2006). Since the jurisdictions of each committee were altered with every reform, comparisons across parliamentary terms are difficult.

In addition, committee positions are assigned at the beginning of each legislature for 2.5 years. About $30 \%$ of MEPs are re-assigned in the second half of each legislature (McElroy, 2006). Limiting the study to 2.5 years allows us to treat the entire period of analysis as a single point in time, in contrast to a complex time-series analysis over several half terms. Empirically, almost half $(45 \%)$ of all reports written in the fifth Parliament were undertaken in the first 2.5 years of the legislative term.

As a result of these concerns and after a careful consideration of the costs and benefits of extending the time frame of the analysis, this paper covers all reports in 13 EP committees between 1 September 1999 and 1 January 2002. Each observation in the data set corresponds to one report. There were 1096 reports in the first 2.5 years of the fifth Parliament, of which 904 were written in the 13 committees included in the analysis. Owing to lack of data on salience, 82 observations had to be excluded. Because the European Parliament's power over policy outcomes varies across the different decisionmaking procedures, the analysis distinguishes between the most influential (co-decision) reports (Co-decision $=1$ ) and other types of reports (Co-decision $=0)$. Data on committee assignments, committee rank (chair, vice-chair, member and substitute) and reports are available online from the European Parliament's website. ${ }^{2}$

The dependent variable (Salience) is defined as the percentage of the electoral manifesto dedicated to a particular policy area. Representation occurs when MEPs engage in policy areas that matter to their constituents. The analysis assumes that, given other incentives to participate in the legislature, MEPs prefer to spend their time on policy areas that matter to their constituents. Electoral manifestos represent the national party's best guess as 
to what matters to its potential voters. No data were available for reports on Budgets, Budgetary Control, Legal Affairs and Petitions. The national party positions used in the construction of the dependent variable are available on the data CD accompanying Budge et al.'s (2001) cross-country study of party manifestos. The coding frame used to match party positions with committee reports is in the appendix. ${ }^{3}$

Figure 1 plots the median salience and the inter-quartile range of each policy area to illustrate its relative popularity and the skewness of the distribution. ${ }^{4}$ The $y$-axis represents the percentage of each national party manifesto dedicated to each policy area. Of course, it should be more difficult to win a report in a policy area that is salient to most MEPs than one that is of interest to only a small number of legislators. Unsurprisingly, Economic and Monetary Affairs (ECON) turns out to be the most salient policy area, with a median of more than 17\%, followed by Justice and Home Affairs (LIBE) and Employment and Social Affairs (EMPL). Agriculture and Rural Development (AGRI), Development and Cooperation (DEVE) and Regional Policy, Transport and Tourism (RETT) feature least prominently in the manifestos. The dashed vertical lines indicate the distance between the first and third quartiles to illustrate the extent of variation in the salience distribution of each

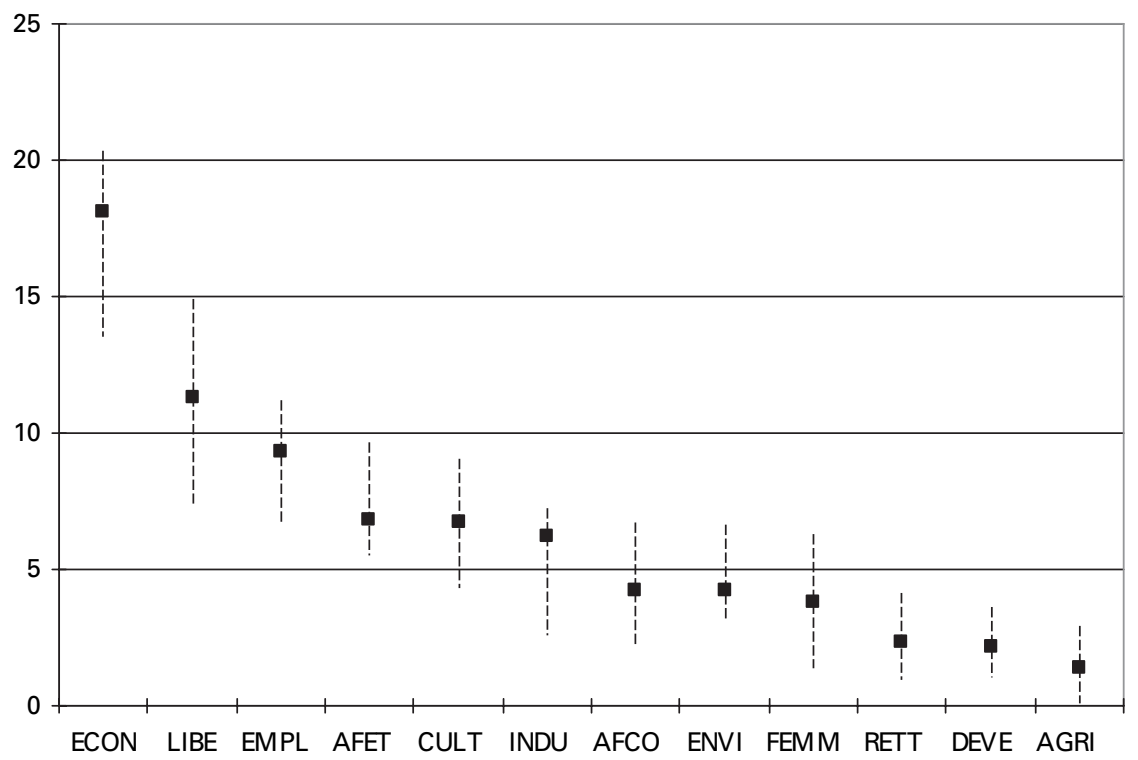

Figure 1 Salience of reports across policy areas.

Note: Markers denote the median salience of the policy area across all MEPs; high-low lines indicate the interquartile range. 
policy area. With the exception of ECON and LIBE, which are by far the most popular, no clear hierarchy emerges.

National party manifestos are, of course, not a perfect measure of salience. Manifestos are political documents created for the specific purpose of convincing voters and winning elections. Clearly, MEPs and their national party voters might not consider the same issues salient in both the European and national contexts. However, parties draw up manifestos as strategic documents focusing on the policy areas that are salient to their potential electorate. European elections are fought by national parties and they have been widely shown to be second-order contests about national rather than European issues (Reif and Schmitt, 1980). As such, national manifestos are a better measure of what is actually salient to constituents than are the manifestos used at European elections.

The manifesto data set has been especially criticized for its interpretation of party policy positions (Laver et al., 2003; but see Klingemann et al., 1994, for a more positive assessment). However, party manifestos are authoritative indications about which policy areas the party wants to focus on and they are widely used in empirical research. The empirical analysis in this paper focuses not on policy positions but on salience. An area is salient if it is prominent in the manifesto, independently of the policy position that the party advocates. Using party manifestos makes it possible to include almost all MEPs in the fifth Parliament without having to rely on expert assessments or public opinion surveys. ${ }^{5}$

Several independent variables are included in the analysis. Incumbency is a dummy variable, which is coded 1 for MEPs who were re-elected in 1999 and 0 for freshmen. Data on ballot structure, candidate selection and the size of electoral districts are taken from Farrell and Scully (2002) and Hix (2004). District is a continuous variable, whereas ballot and candidate selection are coded 0 for open/decentralized systems, 0.5 for order/mixed systems and 1 for closed/centralized systems, respectively. Party size is the number of MEPs for each national party included in the analysis. The distance between an MEP's policy preferences and his/her party group is based on NOMINATE scores for the period July 1999 - January 2002, which are available online. ${ }^{6}$ NOMINATE uses MEP roll-call voting records to determine ideal points for individual legislators across three dimensions (see Hix, 2001, for further details about the NOMINATE methodology). The first dimension is usually interpreted as reflecting a left-right cleavage, whereas the interpretation of the other two dimensions is less clear-cut (see, for instance, Hix et al., forthcoming). In this paper, left-right distance is the absolute difference between an MEP's NOMINATE score on the first dimension and the average of his/her party group. 
Finally, personal expertise in particular policy areas may increase an MEP's chances of obtaining reports in that area. Reliable data on MEP backgrounds are difficult to obtain. However, the EP's list of members published at the beginning of each legislature provides a short overview of every legislator's educational background, work experience and links to interest groups. Because these data are self-reported, they reflect only what MEPs want to say about themselves. Nevertheless, the data do give some indication of a legislator's background in certain policy areas. The empirical analysis in this paper includes dummy variables for self-reported links to trade unions, environmental lobbyists, agricultural, legal or business experience and expertise in the natural sciences and European politics. Descriptive statistics for all variables can be found in the appendix.

\section{Empirical findings}

This section tests the predictions of the model using a combination of bivariate and multivariate statistical tools. Hypothesis 1 suggests that the allocation of salient reports should vary systematically across party groups to reflect coalition patterns within the European Parliament. Figure 2 shows the difference between each party group's share of salient reports and its share of seats. The results are consistent with the hypothesis.

Clearly, some party groups obtain more salient reports than their share of seats in the EP would justify, whereas others get a lower percentage. The largest party group in the fifth Parliament (EPP) is more than $9 \%$ overrepresented, whereas its closest coalition partner on the left-right spectrum, the Liberal ELDR, gets more than $2 \%$ more salient reports than its size would suggest. The main opposition to the EPP, the centre-left PES, also gets $2 \%$ more salient reports. The Greens obtain a slightly larger share of salient reports than their size would predict, which may be because they focus their activity on the Environment committee. The smaller groups at both edges of the political spectrum (European United Left, EUL, and Union for Europe of the Nations, UEN) are most underrepresented.

Although the bivariate analysis in Figure 2 does not allow for any definitive conclusions, it is consistent with the suggestion that the allocation of salient committee reports is a result of committee decision-making rules. ${ }^{7}$ The open rule in committee and plenum reduces the policy incentive for groups that are far from the median voter in the EP to sign up for reports, especially in the most salient policy areas. The further a party group is from the largest delegation in terms of left-right policy preferences, the less likely it is that its MEPs have access to salient reports. The legislative output of each party group 


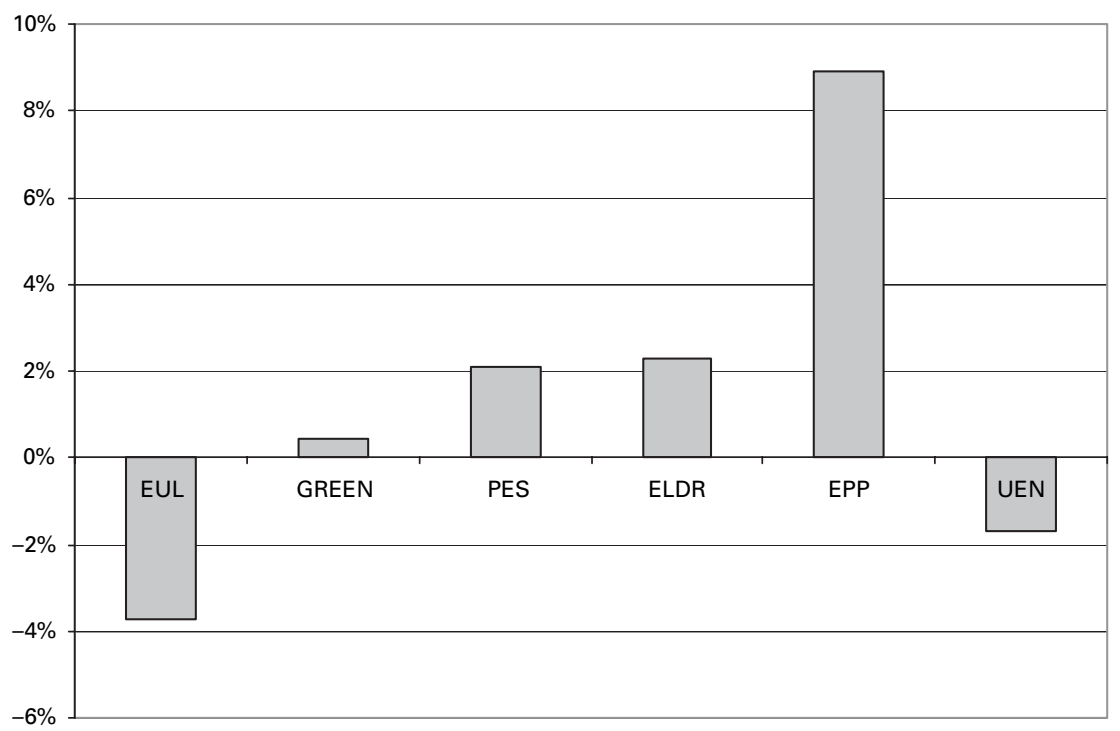

Figure 2 Party representation and share of seats by party group.

Notes: Group for a Europe of Democracies and Diversities (EDD) not represented owing to lack of data. Bars show the difference between a party group's share of salient reports and its share of seats.

depends on its value, in terms of policy preferences, as a coalition partner to the largest group. In other words, Figure 2 is consistent with Hypothesis 1, which suggests that MEPs' ability to represent their constituents is determined by coalition patterns along the left-right spectrum.

The findings indicate that representation, as defined in this paper, is quintessentially political. The open rule in committee and plenum ensures that voting majorities along the left-right spectrum determine the content of reports. As a result, the largest party group (EPP) holds the most salient rapporteurships, followed by its closest coalition partner (ELDR). The distribution of salient reports in Figure 2 qualifies previous research that has explained report allocation as essentially consensual (Benedetto, 2005). At the same time, the results support Kaeding's (2005) suggestion that actors within the EP have different political strategies for legislative participation. Hypothesis 1 explains these strategies in terms of coalition politics. EPP and ELDR MEPs write more salient reports, and therefore represent their constituents better, than do legislators from other party groups because they have the support of a voting majority in the committee and the plenum. The finding also confirms recent research on roll-call votes, which has identified left-right politics as the predominant cleavage in the EP (Hix et al., forthcoming). 
Of course, a purely bivariate analysis does not allow us to assess the statistical significance of these findings, the explanatory power of the model or the relative importance of each of the four hypotheses derived above. Table 3 summarizes the output of two ordinary least squares (OLS) regressions with report salience as the dependent variable. Model (1) includes all reports in all 13 committees whereas model (2) is restricted to the five most legislatively active committees (ENVI, LIBE, INDU, ECON, AFET) ${ }^{8}$ Both models yield very similar results. MEPs' ability to write salient reports depends in large part on the committees that they have joined. Therefore, all regressions incorporate dummies for membership in the committees included in the analysis. All regressions control for differences across electoral systems and the rapporteur's rank within his/her committee, both of which might affect the incentive to sign up for reports that are salient to national party voters. ${ }^{9}$

The regression results support the hypotheses developed in the previous sections. First, in line with the party competition hypothesis (and with Figure 2), both estimations show that MEPs from the largest party group (EPP) write the most salient reports. The coefficients for all other party groups, except its closest coalition partner ELDR, are negative though they do not always assume statistical significance. Because of the open rule in committee and plenum, writing reports in salient policy areas is most valuable (at least from a policy perspective) to MEPs who are part of the majority coalition.

In both models, the extreme left EUL, which is furthest away from the EPP in terms of left-right policy preferences, writes the least salient reports, followed by the biggest opposition party (PES). Substantively, in model (1), Socialists write reports that are $1.1 \%$ less salient than do EPP representatives, which corresponds to $15 \%$ of the mean report salience (7.07\%). Committee reports in salient policy areas are less attractive to MEPs who do not form part of the majority coalition because they can be outvoted in the committee and in the plenum. Finally, the smaller party groups (UEN and Greens) write reports that are as salient as those obtained by the EPP. However, neither of these groups fits very well into the traditional left-right spectrum. Whereas the national parties that form the UEN distinguish themselves from other parties mainly by their euroscepticism, the Greens exhibit a disproportionate preference for environmental policy.

Clearly, coalition patterns have stark consequences for political representation in the European Parliament. The distribution of salient reports reflects the need for EPP and ELDR to cooperate in order to maintain their majority in the Parliament. 'Opposition' MEPs, on the contrary, write less salient reports because they are unlikely to be able to move policy outcomes away from the median legislator owing to the double open rule in committee and plenum. In addition, legislators from smaller party groups (i.e. the Greens) 
Table 3 OLS regression: Dependent variable - report salience

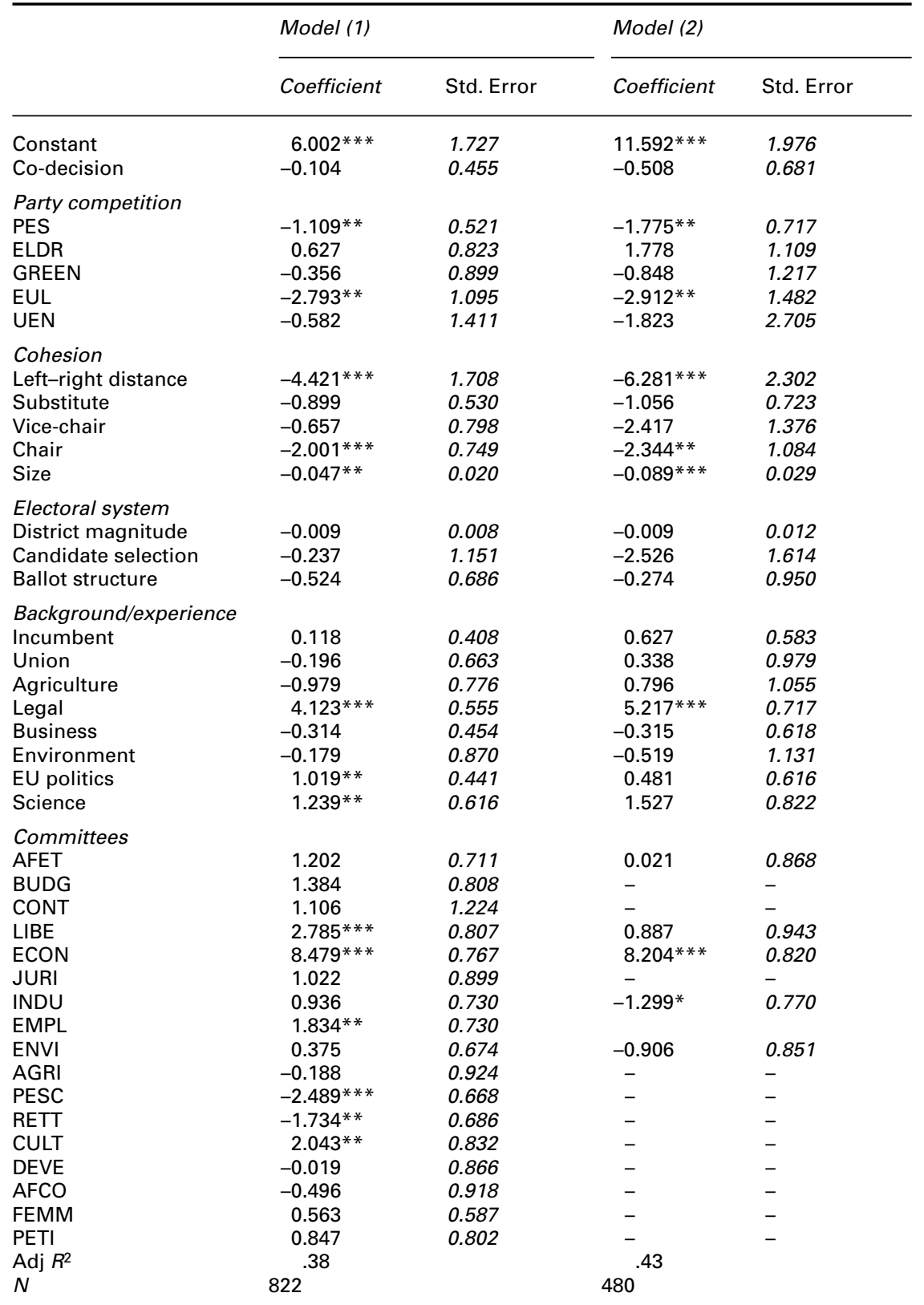

Notes: Group for a Europe of Democracies and Diversities (EDD) and Group of Independents not included owing to lack of data.

*** significant at 0.01 level, ${ }^{* *}$ significant at 0.05 level. 
that focus their activities on a restricted number of policy areas are more successful in gaining rapporteurships that are salient to them than are mainstream MEPs who have to compete with members of other parties with similar preferences.

Apart from competition across party groups, Table 3 also shows considerable evidence for the remaining three hypotheses, which address the link between party group cohesion and political representation. First, preference outliers represent their constituents less well than do MEPs who toe the party line (H4). Every 0.1 increase in an MEP's policy distance from his/her party group leads to a $0.4 \%$ drop in report salience. Because the leadership is concerned with protecting the brand name of the party group and maintaining its credibility, legislators who often defect from their group in roll-call votes are less likely than their colleagues to be assigned salient reports. The leadership screens candidates ex ante to make sure their reports reflect the opinion of the group as a whole. In addition, party leaders use their power to allocate reports ex post to reward MEPs who have toed the party line and to punish defectors. Rebel MEPs are less likely to be assigned salient reports and, therefore, represent their constituents less well than do legislators whose policy preferences are in line with the rest of the party group.

The results also strongly support $\mathrm{H} 2$ and $\mathrm{H} 3$, which address the party group's concern with maintaining loyalty by giving individual legislators a stake in the operation of the party group. In both estimations reported in Table 3, MEPs from smaller national parties write more salient reports than legislators from larger parties (H2). Thus, in line with Kaeding (2005), MEPs from smaller member states (and national party delegations) focus their participation on the policy areas that are most salient to them. At the same time, in order to maintain cohesion, the leadership compensates rank-and-file members who have little influence over the group with disproportionately salient reports.

In addition, committee chairs write less salient reports than regular committee members (H3). The negative relationship between committee rank and report salience is less strong for vice-chairs, and there is virtually no difference between the salience of reports written by full members and those obtained by substitute members. As Corbett et al. (2003) have noted, committee chairs often assume responsibility for reports that none of the rankand-file members want to take on. Regular committee members and substitutes, in contrast, focus their legislative participation on the most salient policy areas.

Finally, none of the electoral system variables and only legal expertise is consistently significant in both estimations. MEPs with a legal background are more successful in obtaining salient rapporteurships than are legislators 
without such expertise. The coefficient on legal experience may partly be explained by the fact that the committee on Legal Affairs (JURI) was excluded from the analysis owing to lack of data. Whereas expertise in a particular policy field is useful in gaining access to the most technically complex reports, it is not clear why these reports should also be the most salient. More surprisingly, incumbency (in both models) and experience with European politics (in model 2) are also insignificant, which confirms much previous research that has questioned the value of seniority in the European Parliament (e.g. Bowler and Farrell, 1995).

\section{Discussion and conclusion}

This paper models the consequences of committee report allocation for political representation in the European Parliament. Both inter- and intra-party group dynamics determine an individual legislator's ability to represent the preferences of his/her national party's electorate. First, party groups compete for salient reports on the basis of their delegation size and left-right policy preferences. Second, the party group leadership distributes these reports among its MEPs in an attempt to maximize the cohesion of the group. As a consequence, MEPs from large national delegations, committee chairs and preference outliers represent their constituents less well than their party group colleagues.

The paper contributes to a number of existing research programmes. Most importantly, perhaps, it expands on the nascent literature on political representation in the EP by examining 'direct representation' from an empirical perspective. In line with Hall (1996), the paper argues that the participation of individual legislators in parliamentary affairs has important consequences for political representation. The structure of opportunities and constraints in the EP conditions which policy areas MEPs engage in and, by implication, whose political opinions are represented in parliamentary debates and in the policy positions that the legislature adopts. The open rule in committee and plenum reduces the incentive for MEPs who are not part of the majority coalition to take on reports in the most salient policy areas. Within party groups, rank-and-file committee members and MEPs from smaller national delegations focus on the most salient reports, whereas their peers participate in a wider range of policy areas.

Most studies of committee reports in the EP analyse the level of participation across policy areas (Raunio, 1997; Mamadouh and Raunio, 2003; Kaeding, 2004, 2005; Høyland, 2005; Hix et al., forthcoming). This paper 
indicates how less directly observable characteristics of legislative participation, such as its representational quality, can be systematically analysed. Apart from opening up a new generation of empirical representation studies that is applicable across a wide range of legislative activities, a similar research design might also be used to analyse, for instance, legislative entrepreneurship in the European Parliament and other legislatures.

In addition, the paper contributes to existing literature on the internal organization of the EP. The model explains disproportionalities in the allocation of salient reports across party groups in terms of coalition politics. The findings corroborate recent studies of party group competition and coalition formation in the EP, which maintain that coalitions are based on the closeness of policy preferences across party groups (e.g. Hix et al., forthcoming). Inter-party group competition for salient reports is likely to increase in importance as the European Parliament acquires further political influence (see Hix et al., forthcoming, for a similar interpretation in their analysis of roll-call votes over time). Similarly, a switch from an open to a closed rule in committee and plenary voting would strengthen the role of the rapporteur and increase competition for salient reports between the majority coalition and other party groups in the EP.

Finally, the paper provides insights into the internal workings of EP party groups. In addition to the different political strategies identified by Kaeding (2005), disproportionalities in the allocation of committee reports within party groups are a result of the leadership's concern with maintaining group cohesion. The findings confirm Kreppel's (2002) conclusion that there are considerable constraints on how the party group leadership allocates its resources. In order to maintain cohesion, group coordinators allow loyal rankand-file members and MEPs from smaller national parties to sign up for those reports that are most salient to them. These constraints are likely to increase in importance as the European Union continues to enlarge and becomes politically more heterogeneous.

This paper is a first attempt empirically to analyse the consequences of legislative participation for political representation in the EP. Future research should test the model developed here in the context of other legislative activities, such as parliamentary questions or committee assignments. Additionally, further research should follow in Whitaker's $(2001,2005)$ footsteps to investigate the internal organization of the party group leadership itself. How do group coordinators, national party leaders, committee chairs and the party group secretariat relate to one another? And what is the effect of the party affiliation of group leaders on the representational performance of their MEPs? 


\section{Notes}

I would like to thank Bjørn Høyland, Tapio Raunio, Richard Whitaker, David Marshall, Achim Goerres, Michael Bruter, Ed Page, Fabio Franchino, Sara Hagemann and four anonymous referees for their extremely valuable comments and suggestions. This research would not have been possible without the financial support of the Luxembourg Ministry of Culture, Higher Education and Research. The data used in the empirical analysis are available from the author upon request.

1 Cohesion in this context refers to the ability of the party group to rally around a common policy position and entice its members to support group goals in their legislative work.

2 See http://www.europarl.eu.int. I would like to thank Bjørn Høyland for sharing these data.

3 The appendix is available on the EUP website. See http://www. uni-konstanz.de/eup/issues.htm.

4 Figure 1 includes all MEPs for whom data were available in order to reflect the size of each national party delegation in the EP.

5 Both these alternative tools for measuring salience have their own disadvantages. Expert surveys are often less comprehensive both in the number of policy areas that they distinguish and in the number of parties covered. In addition, previous research has criticized both public opinion surveys and expert evaluations for a lack of reliability.

6 See http://personal.lse.ac.uk/hix/HixNouryRolandEPdata.HTM.

7 Note, however, that small variations from perfect proportionality could arise even if a proportional allocation rule (such as d'Hondt) were used. In order to test the effect of party group affiliation on representation, a more sophisticated multivariate analysis is needed.

8 Although these are the five committees that produced most reports (codecision and others combined), this does not necessarily reflect their legislative importance (see e.g. Kaeding, 2005, for a different set of seven 'most influential' committees). The model was run on Kaeding's selection of the seven 'most influential' committees. The only substantive change in this estimation was a drop in the significance of the coefficient on the EUL below conventional levels of significance. Note also that the lack of co-decision reports in AFET should not be a problem because the empirical analysis includes all reports and controls for co-decision reports with an appropriate dummy variable.

9 These results remained very similar in a separate analysis excluding the most prolific MEPs (10+ reports). Also, a regression on the subset of co-decision reports only did not alter conclusions. The results were strengthened after inclusion of fixed effects to account for possible variation in representational focus across MEPs from different countries (Table 1). Such country dummies pick up any country-level variation in the data that is not accounted for by other variables in the model. Finally, instead of fixed effects, the model was also run using random country effects and random effects for the different policy areas. None of these re-specifications led to any substantive change in results. These results are available upon request from the author. 


\section{References}

Andeweg, Rudy (1995) 'The Reshaping of National Party Systems', in Jack Hayward (ed.) The Crisis of Representation in Europe, pp. 58-78. London: Frank Cass.

Attinà, Fulvio (1992) 'Parties, Party Systems and Democracy in the European Union', International Spectator 27: 67-86.

Bardi, Luciano (1994) 'Transnational Party Federations, European Parliamentary Party Groups, and the Building of Europarties', in Richard S. Katz and Peter Mair (eds) How Parties Organize: Change and Adaptation in Party Organizations in Western Democracies, pp. 357-72. London: Sage.

Benedetto, Giacomo (2005) 'Rapporteurs as Legislative Entrepreneurs: The Dynamics of the Codecision Procedure in Europe's Parliament', Journal of European Public Policy 12(1): 67-88.

Boucek, Francoise (2002) 'The Structure and Dynamics of Intra-Party Politics in Europe', Perspectives on European Politics and Society 3(3): 453-92.

Bowler, Shaun and David Farrell (1993) ‘Legislator Shirking and Voter Monitoring: Impact of European Parliament Electoral Systems upon Legislator-Voter Relationships', Journal of Common Market Studies 31(1): 45-69.

Bowler, Shaun and David Farrell (1995) 'The Organizing of the European Parliament: Committees, Specialization and Co-ordination', British Journal of Political Studies 25: 219-43.

Budge, Ian, Hans-Dieter Klingemann, Andreas Volkens, Judith Bara and Eric Tanenbaum (2001) Mapping Policy Preferences. Oxford: Oxford University Press.

Carrubba, Clifford (2001) 'The Electoral Connection in European Union Politics', Journal of Politics 63(1): 141-58.

Corbett, Richard, Francis Jacobs and Michael Shackleton (2003) The European Parliament, 5th edn. London: John Harper.

Crombez, Christophe (1997) 'The Co-Decision Procedure in the European Union', Legislative Studies Quarterly 22(1): 97-119.

Crombez, Christophe (2003) 'The Democratic Deficit in the European Union: Much Ado about Nothing?', European Union Politics 4(1): 101-20.

Farrell, David M. and Roger Scully (2002) 'MEPs as Representatives: Individual and Institutional Roles', Journal of Common Market Studies 41: 269-88.

Follesdal, Andreas and Simon Hix (2005) 'Why There is a Democratic Deficit in the EU: A Reponse to Majone and Moravcsik', European Governance Papers (EUROGOV) C-05-02, http:/ / connex-network.org.

Hall, Richard (1996) Participation in Congress. New Haven, CT: Yale University Press.

Hix, Simon (2001) 'Legislative Behavior and Party Competition in European Parliament: An Application of Nominate to the EU', Journal of Common Market Studies 39: 663-88.

Hix, Simon (2002) 'Parliamentary Behaviour with Two Principals: Preferences, Parties, and Voting in the European Parliament', American Journal of Political Science 46: 688-98.

Hix, Simon (2004) 'Electoral Institutions and Legislative Behavior: Explaining Voting-Defection in the European Parliament', World Politics 56(1): 194-223.

Hix, Simon and Christopher Lord (1997) Political Parties in the European Union. London: Macmillan. 
Hix, Simon, Abdul Noury and Gerard Roland (2004) 'Power to the Parties: Competition and Cohesion in the European Parliament, 1979-2001', British Journal of Political Science 34(4): 767-93.

Hix, Simon, Abdoul Noury and Gerard Roland (forthcoming) Democratic Politics in the European Parliament. Cambridge: Cambridge University Press.

Høyland, Bjørn (2005) 'Government-Opposition in Bicameral Negotiations: Decision-Making in European Union's Codecision Procedure', EPRG Working Paper No. 12, URL: http://www.lse.ac.uk/collections/EPRG/workingpapers.htm.

Høyland, Bjørn (2006) 'Allocation of Codecision Reports in the Fifth European Parliament', European Union Politics 7(1): 30-50.

Jun, Hae-Won (2003) 'Catching the Runaway Bureaucracy in Brussels: EuroParliamentarians in Budgetary Politics', European Union Politics 4(4): 421-45.

Kaeding, Michael (2004) 'Rapporteurship Allocation in the European Parliament. Information or Distribution?', European Union Politics 5(3): 355-73.

Kaeding, Michael (2005) 'The World of Committee Reports: Rapporteurship Assignment in the European Parliament', Journal of Legislative Studies 11(1): 82-104.

Katz, Richard (1997) 'Representational Roles', European Journal of Political Research 32: 211-26.

Katz, Richard S. (1999) 'Role Orientations in Parliaments', in Richard Katz and Bernhard Wessels (eds) The European Parliament, the National Parliaments and European Integration, pp. 61-86. Oxford: Oxford University Press.

Klingemann, Hans-Dieter, Richard I. Hofferbert and Ian Budge (1994) Parties, Policies, and Democracy. Boulder, CO: Westview.

Kreppel, Amie (2002) The European Parliament and the Supranational Party System. Cambridge: Cambridge University Press.

Kreppel, Amie and Simon Hix (2003) 'From Grand Coalition to Left-Right Confrontation: Explaining the Shifting Structure of Party Competition in the European Parliament', Comparative Political Studies 36 (1/2): 75-96.

Laver, Michael, Kenneth Benoit and John Garry (2003) 'Extracting Policy Positions from Political Texts Using Words as Data', American Political Science Review 97(2): 311-31.

McElroy, Gail (2006) 'Committee Representation in the European Parliament', European Union Politics 7(1): 5-29.

Majone, Giandomenico (2000) 'The Credibility Crisis of Community Regulation', Journal of Common Market Studies 38(2): 273-302.

Mamadouh, Virginie and Tapio Raunio (2001) 'Allocating Reports in the European Parliament: How Parties Influence Committee Work', EPRG Working Paper No. 7, URL: http://www.lse.ac.uk/collections/EPRG/working-papers.htm.

Mamadouh, Virginie and Tapio Raunio (2003) 'The Committee System: Power, Appointments, and Report Allocation', Journal of Common Market Studies 41(2): 333-51.

Marsh, Michael and Bernhard Wessels (1997) 'Territorial Representation', European Journal of Political Research 32: 227-41.

Moravcsik, Andrew (2002) 'In Defence of the Democratic Deficit: Reassessing Legitimacy in the European Union', Journal of Common Market Studies 40(4): 603-24. 
Moravcsik, Andrew and Andrea Sangiovanni (2002) 'On Democracy and "Public Interest" in the European Union', in Wolfgang Streeck and Renate Mayntz (eds) Die Reformierbarkeit der Demokratie. Innovationen und Blockaden, pp. 122-48. Frankfurt: Campus Verlag.

Müller, Wolfgang (2000) 'Political Parties in Parliamentary Democracies: Making Delegation and Accountability Work', European Journal of Political Research 37: 309-33.

Norris, Pippa and Mark Franklin (1997) 'Social Representation', European Journal of Political Research 32: 185-21.

Pitkin, Hanna F. (1967) The Concept of Representation. London: Cambridge University Press.

Raunio, Tapio (1997) The European Perspective: Transnational Party Groups in the 1989-1994 European Parliament. Aldershot: Ashgate.

Reif, Karl-Heinz and Herrmann Schmitt (1980) 'Nine Second-Order National Elections: A Conceptual Framework for the Analysis of European Election Results', European Journal of Political Research 8(1): 3-44.

Scharpf, Fritz W. (1999) Governing in Europe: Effective and Democratic? Oxford: Oxford University Press.

Schmitt, Herrmann and Jacques Thomassen (eds) (1999) Political Representation and Legitimacy in the European Union. Oxford: Oxford University Press.

Schmitt, Hermann and Jacques Thomassen (2000) 'Dynamic Representation: The Case of European Integration', European Union Politics 1(3): 318-39.

Thomassen, Jacques and Herrmann Schmitt (1997) 'Policy Representation', European Journal of Political Research 32: 165-84.

Tsebelis, George and Geoffrey Garrett (2000) 'Legislative Politics in the European Union', European Union Politics 1(1): 9-36.

Van der Eijk, Cees and Mark Franklin (eds) (1996) Choosing Europe: The European Electorate and National Politics in the Face of Union. Ann Arbor: University of Michigan Press.

Weingast, Barry and William Marshall (1988) 'The Industrial Organization of Congress; or Why Legislatures, Like Firms, Are Not Organized as Markets', Journal of Political Economy 96(11): 132-63.

Wessels, Bernhard (1999) 'Whom to Represent? Role Orientations of Legislators in Europe', in Hermann Schmitt and Jacques Thomassen (eds) Political Representation and Legitimacy in the European Union. Oxford: Oxford University Press.

Whitaker, Richard (2001) 'Party Control in a Committee-Based Legislature? The Case of the European Parliament', Journal of Legislative Studies 7(4): 63-88.

Whitaker, Richard (2005) 'National Parties in the European Parliament - An Influence in the Committee System?', European Union Politics 6(1): 5-28.

Wlezien, Christopher (2004) `Patterns of Representation: Dynamics of Public Preferences and Policy', Journal of Politics 66(1): 1-24. 


\section{About the author}

Pierre Hausemer is a $\mathrm{PhD}$ candidate in the Department of

Government at the London School of Economics and Political Science, Houghton Street, London, WC2A 2AE, UK.

Fax: +44 2079556352

E-mail: p.hausemer@Ise.ac.uk 